\title{
Tarm- og flerorgantransplantasjon ved kronisk tarmsvikt
}

\begin{abstract}
Sammendrag
Bakgrunn. Pasienter med kronisk tarmsvikt behandles primært med parenteral ernæring, ofte i mange år. Hvis det oppstår alvorlige komplikasjoner til intravenøs ernæringsterapi, kan tarm-/flerorgantransplantasjon vurderes. Vi har etablert samarbeid med Sahlgrenska Universitetssjukehuset i Göteborg og Jackson Memorial Hospital i Miami, USA, for å gi et tilbud til norske pasienter med kronisk tarmsvikt.
\end{abstract}

Materiale og metode. Langtidsstudie av sju pasienter med kronisk tarmsvikt behandlet med tarm-/flerorgantransplantasjon lventrikkel, duodenum, pancreas og tynntarm) i perioden 2001-09, fem pasienter i Göteborg og to i Miami. Lever- og nyretransplantasjon ble utført samtidig med tarmtransplantasjonen hos henholdsvis seks og to pasienter.

Resultater. Fire av sju pasienter er i live med tilfredsstillende allmenntilstand 24-120 md. etter transplantasjonen. Graftfunksjonen er tilfredsstillende slik at pasientene i hovedsak tar til seg føde oralt. Tre pasienter døde etter alvorlig infeksjon, henholdsvis 1 , 10 og $24 \mathrm{md}$. etter transplantasjonen.

Fortolkning. Tarm-/flerorgantransplantasjon er en krevende og kostbar behandling. En livslang og tverrfaglig oppfølging av pasientene etter transplantasjonen er nødvendig for tidlig diagnostikk av avstøtninger (rejeksjoner) og infeksjoner. Samarbeid med internasjonale sentre har gitt norske pasienter med kronisk tarmsvikt et behandlingstilbud som ikke er tilgjengelig i Norge.
Øystein H. Bentdal

obentdal@ous-hf.no

Aksel Foss

Seksjon for transplantasjonskirurgi

\section{Anniken Bjørnstad Østensen}

Seksjon for spesialisert barnemedisin og transplantasjon

Barnemedisinsk avdeling

Kvinne og barneklinikken

Knut Lundin

Seksjon for gastromedisin

Inger Nina Farstad

Seksjon for biopsi og autopsi

Avdeling for patologi

Klinikk for diagnostikk og intervensjon

\section{Pål-Dag Line}

Seksjon for transplantasjonskirurgi

Avdeling for transplantasjonsmedisin

Klinikk for spesialisert medisin og kirurgi

Oslo universitetssykehus, Rikshospitalet

Kort tarm-syndrom kan oppstå når tynntarmens lengde er under 75-100 cm. Pasientene får kronisk diaré, går ned i vekt og kan utvikle alvorlig underernæring. Hos barn kan en tarmlengde på $50 \mathrm{~cm}$ være tilstrekkelig da det etter hvert skjer en adaptasjon av tarmmucosa (1). Kronisk tarmsvikt kan også oppstå ved såkalt intestinal pseudoobstruksjon, der tarmen har normal lengde, men ikke absorberer nødvendige næringsstoffer på grunn av motilitetsforstyrrelser. Kronisk tarmsvikt utvikles kun ved sykdom eller skade av tynntarmen. Man kan klare seg uten tykktarmen, men hvis tykktarmen er bevart, vil behovet for ekstra tilførsel av væske og saltløsninger være redusert (2). Tarmtransplantasjon er derfor bare aktuelt når tynntarmen svikter. Resultatene ved slik behandling har inntil 1998 vært vesentlig dårligere enn for andre organtransplantasjoner $(3,4)$. Det er nødvendig å transplantere en stor del av tynntarmen (minimum $2 \mathrm{~m}$ ) fra avdød organgiver for å få akseptabel tarmfunksjon etter inngrepet.

Pasienter med kronisk tarmsvikt kan leve i mange år med akseptabel livskvalitet ved hjelp av total parenteral nutrisjon (TPN) (5). Innleggelse av sentralvenøst kateter er nødvendig for å ha en sikker tilgang til blodbanen og er en absolutt forutsetning for langvarig TPN-behandling. Tarmforlengende kirurgi bør vurderes hos barn med kort tarm-syndrom for å vurdere hvilke pasienter som kan slutte med denne typen ernæring, eventuelt greie seg med intermitterende behandling (6).
Behandlingen kan, særlig hvis den varer i måneder eller år, gi alvorlige komplikasjoner som trombosering av sentrale vener og kateterinfeksjoner som kan føre til livstruende sepsis. I tillegg kan det utvikle seg TPN-assosiert kolestase pga. unormalt seig galle og gallegangssteiner som med tiden kan føre til alvorlig, irreversibel leversvikt.

Et lite antall tarmtransplantasjoner ble utført i 1960- og -70-årene, men programmene ble stanset da ingen av pasientene levde mer enn få måneder etter transplantasjonen (7). Tarmen inneholder et stort antall immunologisk aktive celler som forårsaket en tidlig og kraftig rejeksjon av transplantatet. Alvorlige infeksjoner oppsto fordi tarmmucosa ble skadet av avstøtningsprosessen, slik at bakterier kunne trenge gjennom tarmveggen og over i blodbanen og forårsake alvorlig og livstruende sepsis. Etter at bedre immundempende medikamenter (kalsinevrinhemmere, CNI) ble tilgjengelige, først ciklosporin A fra 1983 og deretter takrolimus fra 1995, forsøkte man igjen å utføre tarmtransplantasjon. For å oppnå akseptable resultater viste det seg nødvendig med ytterligere immundempende behandling $\mathrm{i}$ tillegg til kalsinevrinhemmer. Immunsuppressive protokoller som inneholdt både takrolimus og spesifikt antistoff mot lymfocytter, antitymocyttglobulin (ATG), ga økt transplantat- og pasientoverlevelse (8-10). Tarmtransplantasjon er i dag en etablert behandling ved kronisk tarmsvikt og et internasjonalt register er opprettet i Ontario, Canada (3). Pasientoverlevelsen etter fem år er over $60 \%$ ved flere transplantasjonssentre (10-13).

Resultatene etter tarmtransplantasjon har vært vesentlig dårligere enn ved andre organtransplantasjoner. Tarmtransplantasjon vurderes derfor kun hvis det oppstår alvorlige problemer ved behandling med total parenteral nutrisjon. Ved manglende kartilgang eller

\section{Hovedbudskap}

- Parenteral ernæring er primærbehandling ved kronisk tarmsvikt

- Ved manglende kartilgang, livstruende infeksjoner eller kronisk leversvikt kan tarm-/flerorgantransplantasjon vurderes

- Samarbeid med transplantasjonssentre i Sverige og USA gir pasienter i Norge et tilbud om høyspesialisert behandling med tarm- og flerorgantransplantasjon 
livstruende infeksjonsepisoder etter langvarig behandling vurderes isolert tarmtransplantasjon (fig 1). Ved samtidig kronisk leversvikt vurderes levertransplantasjon i tillegg. Flerorgantransplantasjon (multivisceral transplantasjon) som omfatter ventrikkel, duodenum, pancreas samt tynntarm og lever vil i slike tilfeller ofte være den beste behandlingen (fig 2). I denne artikkelen presenteres erfaringer fra sju norske pasienter som er behandlet med tarm-/multivisceral transplantasjon i utlandet.

\section{Materiale og metode}

Alle pasientene er primært vurdert ved Oslo universitetssykehus, Rikshospitalet før de er blitt akseptert til tarmtransplantasjon. Klinisk informasjon er innhentet fra transplantasjonssykehuset etter inngrepet. Oslo universitetssykehus, Rikshospitalet har hatt ansvaret for oppfølgingen av pasientene etter transplantasjonen, i nært samarbeid med henvisende sykehus.

\section{Preoperativ utredning}

Tilfredsstillende hjerte- og lungefunksjon er en forutsetning for at pasienten kan bli påmeldt Scandiatransplants venteliste, som er en felles venteliste for de fem nordiske landene. Abdominalkar må kartlegges preoperativt med CT-angiografi. Ved leversvikt må det utføres ultralydundersøkelse og MR av lever og galleveier. Flerorgantransplantasjon er kontraindisert ved alvorlige infeksjoner.

\section{Pasienter}

Alle pasientene hadde før transplantasjonen hatt en langvarig sykehistorie med tallrike laparotomier ledsaget av vekttap og redusert allmenntilstand på tross av total parenteral nutrisjon. Årsaken til kort tarm-syndrom var uttalt tarmgangren hos tre pasienter som skyldtes henholdsvis strangulasjon av hele tynntarmen hos to pasienter og trombose $\mathrm{i}$ intestinale mesenterialvener hos en pasient. Intestinal pseudoobstruksjon var indikasjonen for transplantasjon hos tre pasienter, henholdsvis på grunn av Hirschsprungs sykdom med total colonobstruksjon hos barnet og medfødt kryptogen motilitetsforstyrrelse av tarmen hos de resterende to pasientene. Kolektomi ble også utført hos barnet med Hirschsprungs sykdom.

En pasient hadde Gardners syndrom med uttalt colonpolypose og utviklet multiple, store desmoidsvulster intraabdominalt etter total kolektomi. Disse ble forsøkt behandlet med kjemoterapi (Caelyx (doksorubicin) og Dakarbazine) hver fjerde uke. Behandlingen hadde forbigående effekt på veksten av svulstene, men pasienten fikk etter ett år multiple tarmfistler. Tilstanden med en kronisk, intraktabel ileustilstand ble etter hvert uutholdelig for pasienten.

Alle pasienter bortsett fra en hadde utviklet kronisk irreversibel leversvikt etter langvarig total parenteral nutrisjon (spredning $2-25$ år).

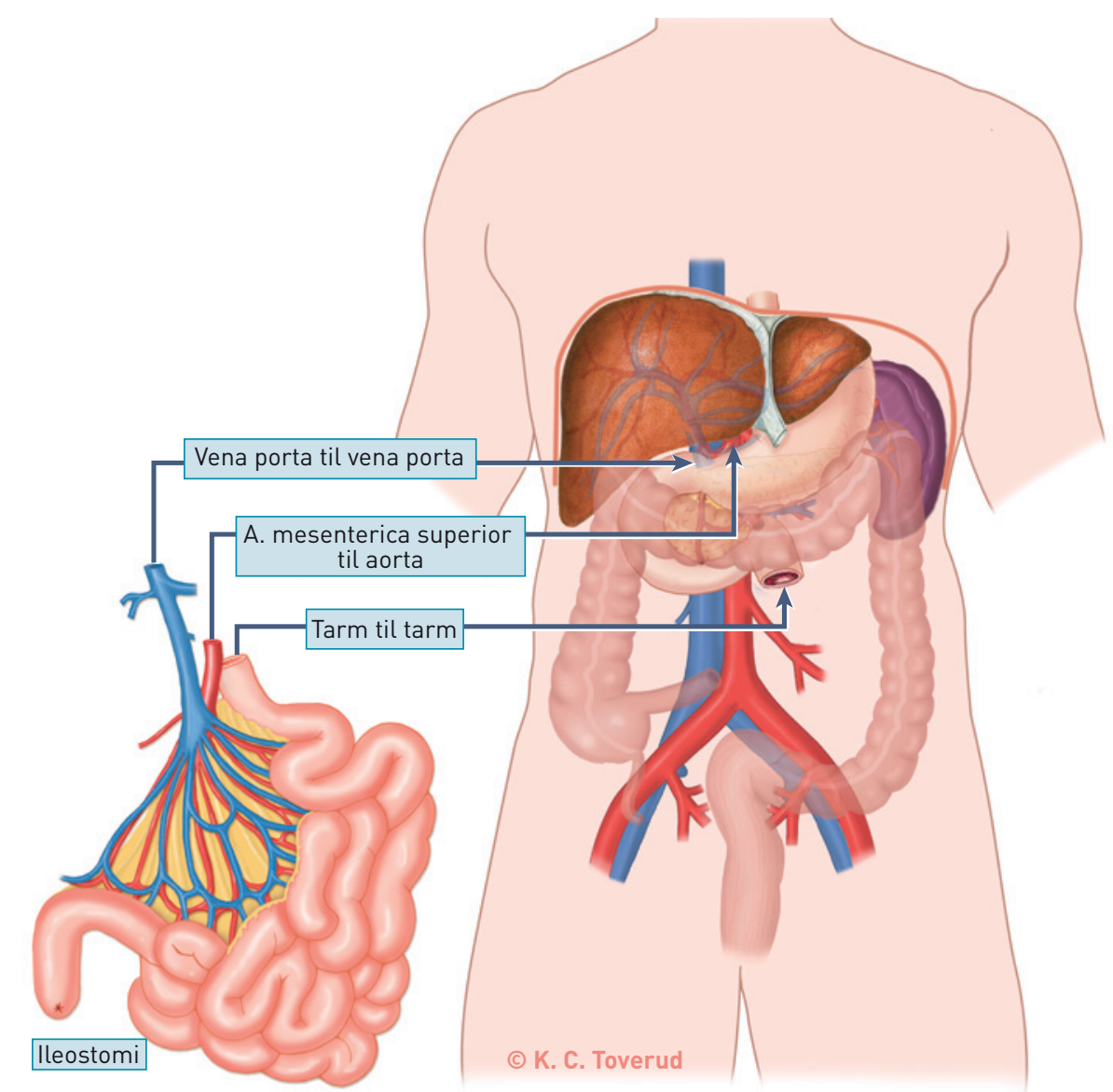

Figur 1 Isolert tarmtransplantasjon med arterie- og portaanastomose i tillegg til tarmanastomose og ileostomi

\section{Inngrep}

Multivisceral transplantasjon (fig 2) ble utført hos alle de sju pasientene og inkluderte levertransplantasjon hos seks pasienter. Pasienten som ikke ble levertransplantert hadde også kolestase, men årsaken viste seg å være multiple gallegangssteiner. Pasienten med mesenterial venetrombose var blitt levertransplantert to måneder tidligere. Okkludert portvene med fortsatt portal hypertensjon og massiv ascitesproduksjon og variceblødninger fra oesophagus var indikasjon for retransplantasjon av lever. I Miami ble milten inkludert $\mathrm{i}$ flerorgantransplantatet hos begge pasientene og hos en ble også hele bukveggen transplantert pga. multiple arrdannelser. Arteria og vena epigastrica inferior til bukveggstransplantatet ble anastomosert til iliakalkarene med mikrokirurgisk teknikk. To pasienter fikk i tillegg utført nyretransplantasjon på grunn av kronisk nyresvikt.

\section{Postoperativ oppfølging}

Faren for rejeksjon og infeksjon er meget stor $(90 \%)$ de første månedene etter transplantasjonen. Daglige blodprøver med tett klinisk observasjon inkludert måling av væskemengden fra ileostomien er viktig $\mathrm{i}$ tidlig postoperativ fase. Det tas initialt tre til fire biopsier 1-2 ganger/uke fra den transplanterte tarmen ved hjelp av fleksibelt endoskop via ileostomien; ved tidlige tegn til rejeksjon kan adekvat behandling startes umiddelbart. Gradering av rejeksjonen baseres både på endoskopiske og mikroskopiske funn som forutsetter spesialkompetanse i endoskopi og patologi (14). Ukentlig monitorering med både CMV- og EBV-PCR er viktig for å oppdage virus reaktivering/ infeksjon.

\section{Etikk}

Skriftlig samtykke til publisering er gitt for alle pasientene i manuskriptet. For pasienter som er døde ble samtykket gitt av pårørende. Personvernombudet har gitt tillatelse til publisering. Studien er ikke meldt regional etisk komité (REK) siden det dreier seg om fortløpende håndtering og behandling av pasienter med kronisk tarmsvikt og hvor etablert behandling har foregått i Sverige og Miami i en årrekke (siden 1995).

\section{Resultater}

I alt har sju norske pasienter fått utført flerorgantransplantasjon i perioden 2001-09, fem i Göteborg og to i Miami. En pasient var et barn (jente, fire år) og de resterende seks var voksne kvinner og menn i alderen 27-48 år. Det operative inngrepet var ofte langvarig (spredning 12-40 timer) og komplisert pga. tidligere kirurgiske inngrep hos de fleste pasientene. En kronologisk oversikt av resultatene fremgår av tabell 1 . 


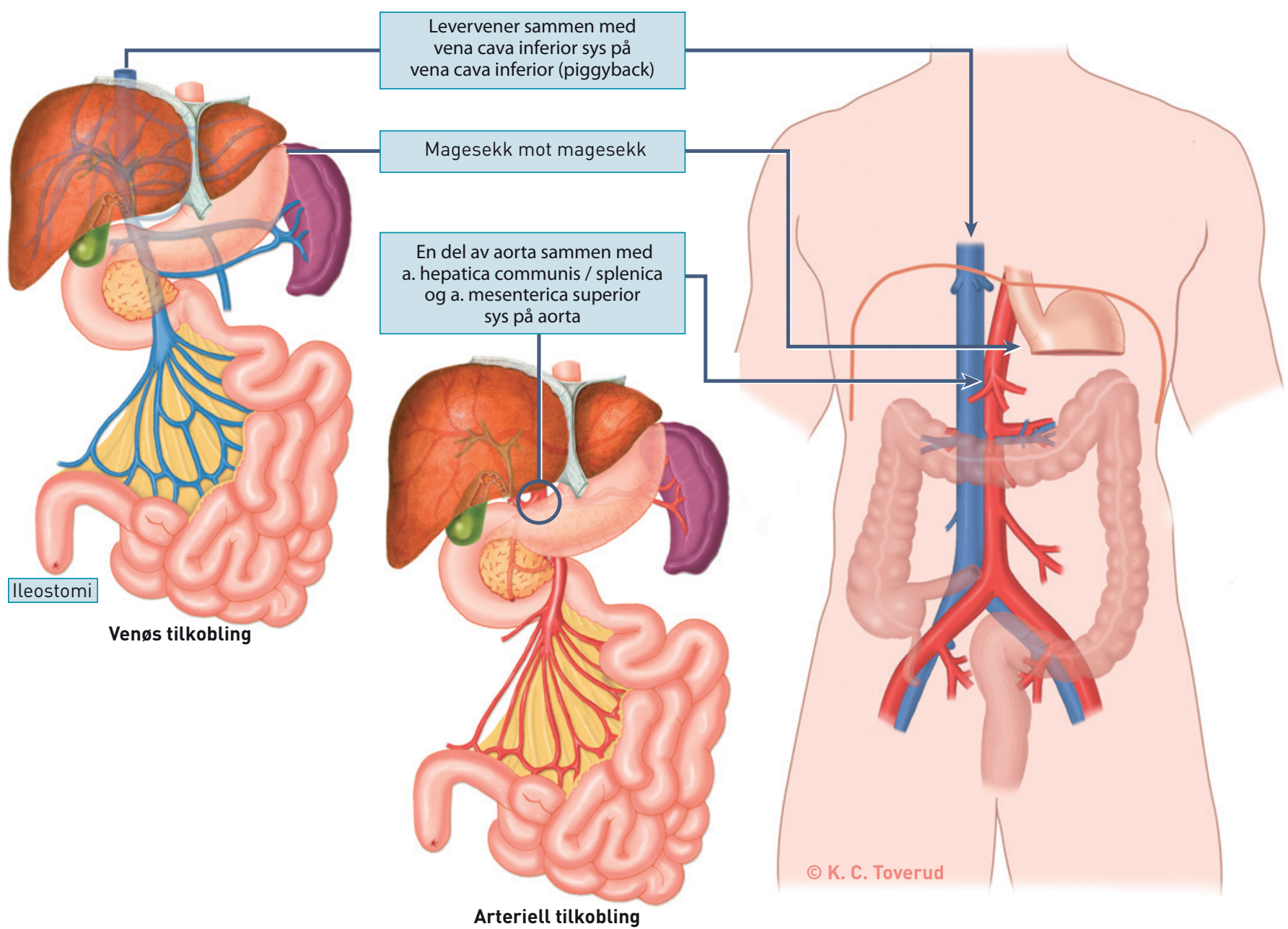

Figur 2 Flerorgantransplantasjon (multivisceral transplantasjon) som omfatter tynntarm, ventrikkel, duodenum, pancreas og lever. Det kan også være aktuelt å inkludere milt og bukvegg. Portvenen er intakt. Det anlegges en «piggyback» cavaanastomose

\section{Rejeksjoner}

Alle pasientene har hatt 1-2 rejeksjoner i tynntarmen bortsett fra en pasient som hadde fått strålebehandling på grunn av testikkelseminom 15 år før transplantasjonen. Akutte avstøtninger er behandlet med høye doser steroider (opptil $1 \mathrm{~g}$ metylprednisolon daglig i fire dager) og i tillegg monoklonalt antiCD3-antistoff (OKT-3) ved steroidresistent rejeksjon som ikke responderer på standard steroidbehandling.

\section{Øvrige komplikasjoner}

Seks av pasientene har hatt $1-6$ reoperasjoner pga. intraabdomial abscess (fire pasienter), gallelekkasje (to pasienter) og tarmfistler (to pasienter). I tillegg har alle pasientene hatt flere infeksjonsepisoder; utløst bakterielt

Tabell 1 Kronologisk oversikt over norske pasienter som har fått utført tarm-/flerorgantransplantasjon i utlandet i perioden 2001-09

Pasient

\section{Alder (år) Kjønn Diagnose}

\begin{tabular}{|c|c|c|}
\hline 45 & $\hat{\sigma}$ & $\begin{array}{l}\text { Stråleskadet tarm } \\
\text { Kort tarm-syndrom }\end{array}$ \\
\hline 27 & $\hat{\sigma}$ & $\begin{array}{l}\text { Strangulasjonsileus } \\
\text { Kort tarm-syndrom }\end{array}$ \\
\hline
\end{tabular}

$33 \quad$ Gardners syndrom. Desmoid

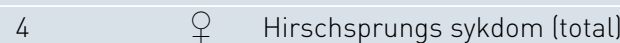

37 ㅇ Pseudoobstruksjon

48 ô Portvenetrombose

Senere også levertrans-

plantasjon

34

34 P + Pseudoobstruksjon

\section{Behandling}

\section{Transplantasjon}

Flerorganstransplantasjon, inkl. nyre

Flerorganstransplantasjon

Flerorganstransplantasjon uten lever

Flerorganstransplantasjon, inkl. nyre

Flerorganstransplantasjon, inkl. nyre

Flerorganstransplantasjon

\section{Sted}

Miami

Göteborg

Miami

Göteborg 2005

Göteborg 2005

Göteborg 2008

2001

\section{Resultat}

Rejek- Reopera- Status (tid etter sjon (n) sjon (n) transplantasjon)

0

2

I live (120 md.)

$2002 \quad 1 \quad$ Død (1 md.)

$2005 \quad 6 \quad$ Død (24 md.)

2005

1

$0 \quad$ I live (76 md.)

12 Død (10 md.)

$2 \quad 1 \quad$ I live (36 md.)


eller av cytomegalovirus (CMV) eller Epstein-Barr-virus (EBV). En pasient utviklet ulcerasjon i ventrikkelen to år etter transplantasjonen; biopsi viste EBV-positivt lymfom forenlig med såkalt PTLD (lymfoproliferativ posttransplantasjonssykdom). Lesjonen tilhelet etter reduksjon av immunsuppresjonen.

\section{Langtidsresultater}

Fire av sju pasienter er i live med tilfredsstillende allmenntilstand 1-10 år etter transplantasjonen. Disse pasientene tar i hovedsak til seg føde på normal måte og er ikke lenger avhengig av total parenteral nutrisjon, men må i perioder få væske og elektrolytter intravenøst. Tre pasienter døde etter alvorlig infeksjoner henholdsvis 1,10 og 24 md. etter transplantasjonen. To av de tre pasientene som døde, hadde nedsatt ernæringstilstand med BMI under $15 \mathrm{~kg} / \mathrm{m}^{2}$ preoperativt. Den tredje pasienten døde 24 md. etter tarmtransplantasjonen, i forbindelse med sepsis etter nyretransplantasjon.

\section{Diskusjon}

Foreløpig har vi i Norge ingen egen erfaring med tarmtransplantasjoner. Overlevelsen hos våre pasienter behandlet $\mathrm{i}$ samarbeid med Göteborg og Miami er på linje med resultater rapportert i litteraturen (60\% femårsoverlevelse) (14). Tidlig henvisning av tarmsviktpasienter til Oslo universitetssykehus, Rikshospitalet er avgjørende for å optimalisere operasjonstidspunktet slik at pasienten kan få et best mulig utfall (fig 3). Isolert tarmtransplantasjon er en mindre og teknisk enklere operasjon sammenliknet med flerorgantransplantasjon, hvor organtilgangen i tillegg er begrenset. Immunologisk sett er imidlertid isolert tarmtransplantasjon like utfordrende som flerorgantransplantasjon $(12,13)$.

I Danmark har man valgt å sentralisere behandlingen av kronisk tarmsvikt til København og Århus siden det må opprettes tverrfaglige team for å tilby optimal oppfølging (15). Det er spesielt viktig å unngå TPN-assosiert kolestase hvor primærtiltaket er redusert tilførsel av lipider gitt intravenøst (5). Kliniske studier har vist at fettemulsjoner som inneholder en blanding av soya-, kokos-, oliven- og fiskeolje gir mindre kolestase, spesielt hos barn (16). Randomiserte studier med såkalte SMOF-lipider ved kronisk tarmsvikt pågår både i Europa og USA (17).

Etablering av tarmtransplantasjonsprogram krever deltakelse av en rekke spesialister innen flere indremedisinske spesialiteter (gastroenterologi, hepatologi, pediatri), transplantasjonskirurgi og anestesiologi samt spesialsykepleie. I tillegg er mange andre spesialiteter og faggrupper viktige $i$ den omfattende utredningen og behandlingen av pasienter med tarmsvikt (medisinsk biokjemi, mikrobiologi, transplantasjonsimmunologi, radiologi, patologi, ernæringsfysiologi, fysioterapi, fysikalsk medisin og rehabilitering og sosialmedisin).

Behandlingen er ressurskrevende med en

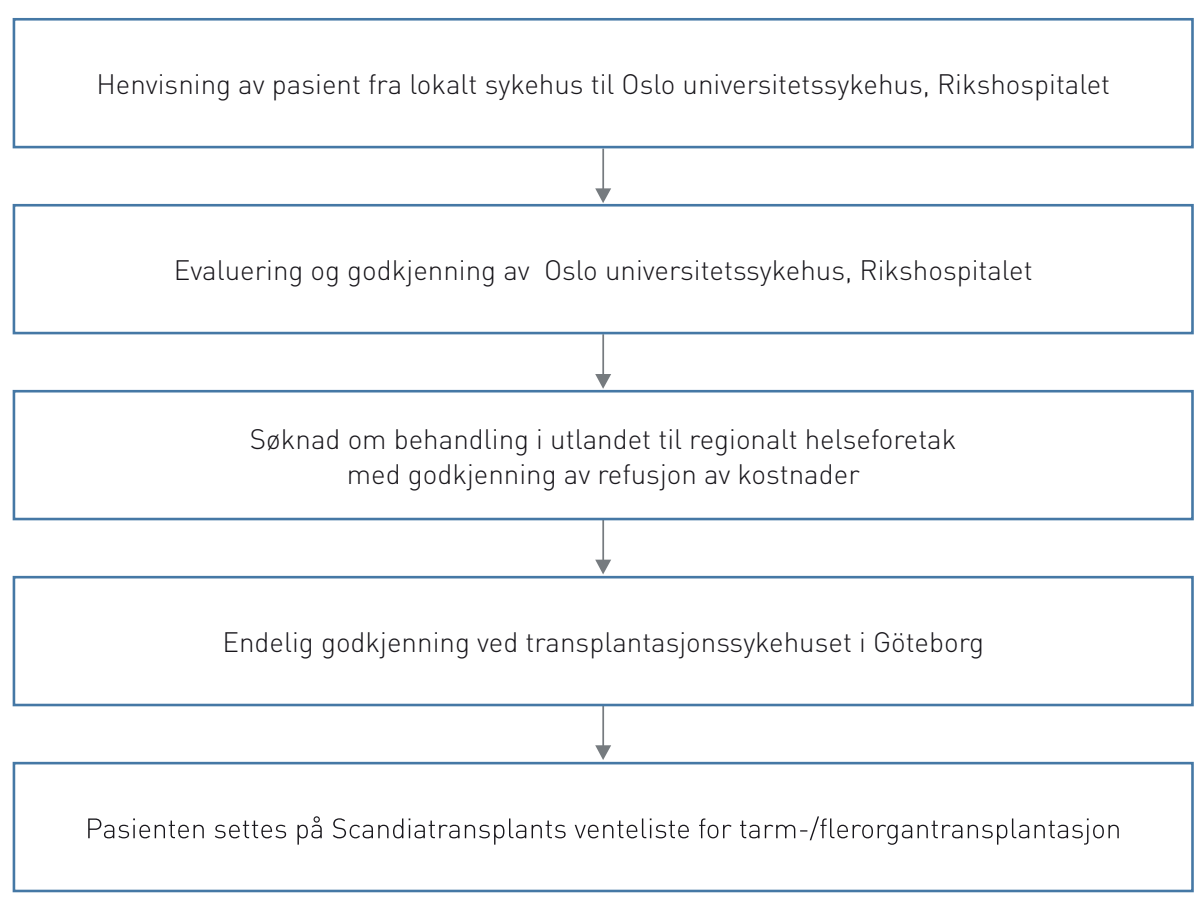

Figur 3 Henvisningsrutiner ved kronisk tarmsvikt

kostnad som i dag er minst tre ganger kostnaden for levertransplantasjon alene, minimum 3 millioner kroner. Medikamentene antas å koste 100000 kroner årlig. Etter ti år kan man beregne at hvert ekstra vunnet leveår har kostet minst 400000 kroner. Til sammenlikning er kostnadene for behandling med total parenteral nutrisjon rundt 1 million kroner $\mathrm{i}$ året. Etter vellykket tarmtransplantasjon kan pasienter med kronisk tarmsvikt oppnå mange gode leveår med en tilfredsstillende livskvalitet. Det må likevel fortløpende vurderes av samfunnet om dette er riktig bruk av helseressursene. Behandlingen er aktuell for bare et fåtall yngre pasienter (øvre aldersgrense 50 år). I en prioriteringsdebatt kan man diskutere hvilke pasienter med alvorlige og sjeldne lidelser som skal tilbys en kostbar behandling, fremfor pasienter med sykdommer hvor behandlingskostnadene er langt lavere. Pasienter og pårørende må informeres om at tarmtransplantasjon trolig er moderne medisins mest kompliserte behandling og at behandlingen kan være svært belastende for pasienten.

Flerorgantransplantasjoner er spesielt ressurskrevende, og forutsetter at det tverrfaglige teamet behandler et tilstrekkelig antall pasienter for å kunne opparbeide og vedlikeholde nødvendig kompetanse. Fagmiljøet ved Oslo universitetssykehus, Rikshospitalet mener at vi også i tiden fremover skal basere oss på samarbeid med Sahlgrenska universitetssjukehuset i Göteborg så lenge de har kapasitet til å behandle både egne og norske pasienter. I helt spesielle tilfeller kan det være aktuelt å henvise pasienten til transplantasjonssentre i USA, som i dag har størst erfaring med tarmtransplantasjoner. Det kreves et stort befolkningsgrunnlag for å opprettholde nødvendig ekspertise for at pasienter med kronisk tarmsvikt skal få tilbud om livreddende behandling med tarm- og flerorgantransplantasjon. Siden behovet for tarmtransplantasjon i Norge hittil har vært 1-2/år, har det vært enighet i fagmiljøet ved Oslo universitetssykehus, Rikshospitalet om ikke å starte et eget nasjonalt program.

\section{Øystein H. Bentdal (f. 1948)}

er spesialist i generell kirurgi og transplantasjonskirurgi (EU), dr.med. og overlege ved Seksjon for transplantasjonskirurgi. Forfatter har fylt ut ICMJE-skjemaet og oppgir ingen interessekonflikter.

\section{Aksel Foss (f. 1955)}

er seksjonsoverlege og professor i transplantasjonskirurgi.ved Oslo universitetssykehus, Rikshospitalet. Han er medlem av ESOT Council (European Society of Organ Transplantation). Forfatter har fylt ut ICMJE-skjemaet og oppgir ingen interessekonflikter.

\section{Anniken Bjørnstad Østensen (f. 1960)}

er spesialist i barnesykdommer med spesialkompetanse i levertransplantasjon av barn. Forfatter har fylt ut ICMJE-skjemaet og oppgir ingen interessekonflikter.

\section{Knut Erik Aslaksen Lundin (f. 1958)}

er overlege, dr.med., førsteamanuensis, spesialist $\mathrm{i}$ indremedisin og fordøyelsessykdommer. Han er p.t. leder for Gastroundersøkelse, Avdeling for organtransplantasjon, fordøyelses- og nyresykdommer, Oslo universitetssykehus, Rikshospitalet, og har bistilling i Centre for immune regulation, Universitetet i Oslo.

Forfatter har fylt ut ICMJE-skjemaet og oppgir følgende interessekonflikter: Han er styremedlem i ImmunsanT og har mottatt forelesningshonorar fra Abbott og MSD. 


\section{Inger Nina Farstad (f. 1957)}

er spesialist i patologi, med spesialkompetanse innen gastroenterologisk patologi og doktorgrad innen immunologi. Hun er avdelingsleder ved den fusjonerte Avdeling for patologi i Oslo universitetssykehus.

Forfatter har fylt ut ICMJE-skjemaet og oppgir ingen interessekonflikter.

\section{Pål-Dag Line (f. 1960)}

er dr.med., overlege i transplantasjonskirurgi og avdelingsleder ved Avdeling for transplantasjonsmedisin, Oslo universitetssykehus. Forfatter har fylt ut ICMJE-skjemaet og oppgir ingen interessekonflikter.

\section{Litteratur}

1. Nightingale J, Woodward JM. Guidelines for management of patients with a short bowel. Gut 2006; 55 (suppl 4): iv1-12.

2. Gouttebel MC Saint Aubert B, Colette C et al. Intestinal adaptation in patients with short bowel syndrome. Measurement by calcium absorption. Dig Dis Sci 1989; 34: 709-15.

3. The Intestinal Transplant Registry. www.lhsc.on.ca/itr/

4. Grant D Abu-Elmagd K, Reyes J et a. 2003 report of the intestine transplant registry: a new era has dawned. Ann Surg 2005; 241: 607-13.

5. Messing B, Crenn P, Beau P et al. Long-term survival and parenteral nutrition dependence in adult patients with the short bowel syndrome. Gastroenterology 1999; 117: 1043-50.

6. Le HD, Fallon EM, de Meijer VE et al. Innovative parenteral and enteral nutrition therapy for intestinal failure. Semin Pediatr Surg 2010; 19: 27-34.

7. Kirkman RL. Small bowel transplantation. Transplantation 1984; 37: 429-33

8. Bond GJ, Mazariegos GV, Sindhi R et al. Evolution ary experience with immunosuppression in pediatric intestinal transplantation. J Pediatr Surg 2005; 40: 274-9, discussion 279-80.

9. Pirenne J, Kawai M. Intestinal transplantation: evolution in immunosuppression protocols. Curr Opin Organ Transplant 2009: 14: 250-5.

10. de Ville de Goyet J. Place of transplantation in infant intestinal failure management. Transplantation 2000; 69: 1234-6

11. Herlenius G, Krantz M, Finkel Y et al. Tarmtransplantation-experimentell terapi som blivit realistiskt alternativ. Läkartidningen 2004; 101: 2874-8.
12. Nishida S, Levi DM, Kato T et al. Ninety-five cases of intestinal transplantation at the University of Miami. J Gastrointest Surg 2002; 6: 233-9.

13. Tzakis AG, Kato T, Levi DM et al. 100 multivisceral transplants at a single center. Ann Surg 2005; 242. 480-90, discussion 491-3.

14. Ruiz P, Kato T, Tzakis A. Current status of transplantation of the small intestine. Transplantation 2007; 83: 1-6.

15. Ladefoged K, Ølgaard K. Sodium homeostasis after small-bowel resection. Scand J Gastroenterol 1985; 20: 361-9

16. Reinshagen $\mathrm{K}$, Kabs $\mathrm{C}$, Wirth $\mathrm{H}$ et al. Long-term outcome in patients with short bowel syndrome after longitudinal intestinal lengthening and tailoring. J Pediatr Gastroenterol Nutr 2008; 47: 573-8.

17. Mertes N, Grimm H, Fürst P et al. Safety and efficacy of a new parenteral lipid emulsion ISMOFlipid) in surgical patients: a randomized, doubleblind, multicenter study. Ann Nutr Metab 2006; 50: $253-9$

Mottatt 23.8. 2011, første revisjon innsendt 2.1. 2012, godkjent 26.1. 2012. Medisinsk redaktør Erlend T. Aasheim. 